\title{
Study of destruxin B and tea saponin, their interaction and synergism activities with Bacillus thuringiensis kurstaki against Spodoptera exigua (Hübner) (Lepidoptera: Noctuidae)
}

\author{
Muhammad Rizwan-ul-HaQ, Qiong Bo Hu, Mei Ying Hu, ${ }^{*}$ Guohua Zhong and \\ Qunfan Weng
}

Key Laboratory of Natural Pesticide and Chemical Biology (Ministry of Education), South China Agriculture University; Guangzhou, 510640, P.R. China

(Received 22 October 2008; Accepted 9 March 2009)

\begin{abstract}
This study reveals the individual and synergistic effects of destruxin B (DB) (mycotoxin from Metarhizium anisoplae), tea saponin (Ts) and Bacillus thuringiensis (Bt) against Spodoptera exigua. $\mathrm{DB}$, Ts and $\mathrm{Bt}$ reduced the growth of neonate larvae by up to $91.30,89.17$ and $77.17 \%$. $\mathrm{EC}_{50}$ values of $\mathrm{DB}$ against 4 th and 5 th instars were 0.17 and $0.22 \mathrm{mg} \mathrm{ml}^{-1}, 0.35$ and $0.41 \mathrm{mg} \mathrm{ml}^{-1}$ against 4 th and 5th instars for Ts and 0.0031 and $0.0035 \mathrm{mg} \mathrm{ml}^{-1}$ after being treated with Bt. The synergism of DB and Ts with Bt resulted in the increased efficiency of these chemicals as mortality percentages significantly increased up to $94.2 \%$ with $\mathrm{DB}+\mathrm{Ts}+\mathrm{Bt}$ followed by $\mathrm{DB}+\mathrm{Bt}$ with $91.99 \%$ and were significantly higher than individual treatments of $\mathrm{Bt} 65.81 \%$ and $\mathrm{Ts} 76.66 \%$. Nutritional analysis revealed the increased toxicity of $\mathrm{DB}$ and $\mathrm{Ts}$ in combination with $\mathrm{Bt}$, but $\mathrm{DB}+\mathrm{Bt}$ showed higher efficiency with minimal relative consumption rate (RCR) $2.69 \mathrm{mg} / \mathrm{mg} /$ day, relative growth rate (RGR) $1.33 \mathrm{mg} / \mathrm{mg} /$ day and efficiency of conversion of ingested food (ECI) $35.77 \%$, respectively. Changes in antioxidant enzymes, superoxidase dismutase (SOD) and catalases (CAT), were noticed to some extent over different exposure times in all treatments. The highest SOD activity was observed in individual DB treatment, while individual Bt treatment caused the highest variation in CAT values. In all treatments, SOD and CAT values fell sharply on the final day except for individual Bt treatment, with which the values were relatively stable on the final day.
\end{abstract}

Key words: Spodoptera exigua; destruxin B; Tea saponin; Bacillus thuringiensis

\section{INTRODUCTION}

The use of conventional insecticides over a long period of time has caused an imbalance in the ecosystem by effecting natural enemies and the environment, and has become a high risk to human health. This exhaustive use of insecticides has also resulted in increased resistance in many important pest species. Spodoptera exigua is a species that has developed resistance against most pesticides groups (Wu et al., 1995; Moulton et al., 2000; Wang et al., 2001).

$S$. exigua caterpillars are destructive crop pests responsible for considerable annual economic losses (Jacques et al., 2008). Since 1986, S. exigua emerged as a serious pest throughout eastern and central provinces, especially in Huanghuai and Jianghuai districts, in China. S. exigua damaged more than $30,000 \mathrm{~km}^{2}$ only in Henan and Shandong provinces during 1999 (Luo et al., 2000). This insect is not only the major agricultural pest, particularly in the southern USA and Asia, but its management is confounded by its migratory dispersal and rapidly evolving resistance to conventional pesticides (Adamczyk et al., 2003; Shimada et al., 2005).

During the last 20 years, much attention has been devoted to natural pest control agents (Ujvary, 2002). In these natural agents, the role of destruxins (mycotoxin from entomophagous fungi Metarhizium anisoplae) has been very important. Destruxins are cyclodepsipeptidic mycotoxins iso-

* To whom correspondence should be addressed at: E-mail: humy@scau.edu.cn DOI: $10.1303 / \mathrm{aez} .2009 .419$ 
lated from the extracellular culture medium of Metarhizium anisoplae (Metch.) and their insecticidal activity has been proved by many authors against different insect species and has also been found to have synergistic activity with other natural agents, such as Bacillus thuringiensis (Bt), against some insects (Brousseua et al., 1998). Similarly, plants produce a variety of compounds that provide certain protection against insect attack (Felton and Gatehouse, 1996). Glycosylated sterols or triterpenoids, known as saponins, have been identified in 80 plant families and many have been found to interfere with insect growth and development (Adel et al., 2000). Bt has been successfully tested against more than 137 insect species of Lepidoptera, Hymenoptera, Diptera and Coleoptera (Gill et al., 1992), but in the recent years there have been many reports on the development of resistance to $\mathrm{Bt}$ (Tabashnik and Carriere, 2004). The combinations of biopesticides and $\mathrm{Bt}$ can be helpful to ease the increasing problem of resistance (Senthil Nathan et al., 2006).

The toxic effects of biochemicals on insects can be manifested in several manners, including toxicity, mortality, antifeedent growth inhibition and efficiency against defense system of pests. Antioxidant enzymes, such as superoxide dismutase (SOD) and catalase (CAT), form an important part of the defense system (Joanisse and Storey, 1996), protecting cells against reactive oxygen species. Oxidative stress after exposure to pesticides and other xenobiotics has been widely documented within the animal kingdom (Harris, 1992; Adamski and Ziemnicki, 2004; Suzuki et al., 2004; Yang et al., 2004) and could contribute to developing resistance in insects.

Biochemicals can be degraded more easily than conventional insecticides so these chemicals must be the main focus of pest management in this era; therefore, the present investigation was undertaken to study the insecticidal activities of destruxin B (DB, a mycotoxin from Metarhizium anisoplae) and tea saponin (Ts, glycoside compound extracted from Camellia seeds) individually, in combination, and with Bt against $S$. exigua (Hübner) to determine their interactive and synergistic impact on bio-efficacy, nutritional efficiency and antioxidative defense system (SOD, CAT in the fat bodies of insects).

\section{MATERIALS AND METHODS}

Insects. Larvae of S. exigua Hübner (Lepidoptera: Noctuidae) were reared on a semi-synthetic diet (David et al., 1975) and kept in growth chambers at $26 \pm 2{ }^{\circ} \mathrm{C}$ with a $16 \mathrm{~L} 8 \mathrm{D}$ photoperiod.

Chemicals. Destruxin B (DB) was isolated from strain MaQ10 of Metarhizium anisoplae (Metch.) according to the references (Pais et al., 1981; Liu et al., 2004; Hu et al., 2006). Destruxin was identified by high-performance liquid chromatography (HPLC), mass spectrometry, and quantified with standards by HPLC. DB was mixed with acetone ( $5 \mathrm{mg}$ in $1 \mathrm{ml}$ ) as a stock solution and diluted with distilled water to make different concentrations.

Tea saponin (Ts) is commercially available and was purchased from Chenxi County Hanqing BioTechnology Co., Ltd. (Hunan, China). It was dissolved in 5\% methanol as a stock solution and different concentrations were prepared with distilled water.

B. thuringiensis (Bt) was purchased from Yangzhou lu-yuan Biochemical Ltd. (Yangzhou, China) at a concentration of $16,000 \mathrm{IU} / \mathrm{mg}$. Different concentrations of Bt were prepared with distilled water to study individual and synergistic effects with DB and Ts.

\section{Evaluation of bio-efficacy.}

$E C_{50}, L C_{50}$ of $D B, T s, B t$ and effect on larval growth. In this experiment $\mathrm{DB}, \mathrm{Ts}$ and $\mathrm{Bt}$ were used to determine their individual effects on the growth of early instars of S. exigua. For this purpose, 1-day-old neonate larvae were placed on $1 \mathrm{~g}$ fresh artificial diet. Insects were placed individually in separate cups (Koul et al., 1990). Artificial diet was treated with six concentrations of $\mathrm{DB}$ [DB1 $(90 \mu \mathrm{g} / \mathrm{ml})$, DB2 $(75 \mu \mathrm{g} / \mathrm{ml})$, DB3 $(60 \mu \mathrm{g} /$ $\mathrm{ml})$, DB4 $(45 \mu \mathrm{g} / \mathrm{ml})$, DB5 $(30 \mu \mathrm{g} / \mathrm{ml})$, DB6 $(15$ $\mu \mathrm{g} / \mathrm{ml})]$, Ts [Ts1 $(90 \mu \mathrm{g} / \mathrm{ml})$, Ts2 $(75 \mu \mathrm{g} / \mathrm{ml})$, Ts3 $(60 \mu \mathrm{g} / \mathrm{ml})$, Ts4 $(45 \mu \mathrm{g} / \mathrm{ml})$, Ts5 $(30 \mu \mathrm{g} / \mathrm{ml})$, Ts6 $(15 \mu \mathrm{g} / \mathrm{ml})]$ and Bt [Bt1 $(1.9 \mu \mathrm{g} / \mathrm{ml}), \mathrm{Bt} 2(1.6$ $\mu \mathrm{g} / \mathrm{ml}), \mathrm{Bt} 3(1.30 \mu \mathrm{g} / \mathrm{ml}), \mathrm{Bt} 4(1.0 \mu \mathrm{g} / \mathrm{ml}), \mathrm{Bt} 5(0.70$ $\mu \mathrm{g} / \mathrm{ml})$, Bt6 $(0.40 \mu \mathrm{g} / \mathrm{ml})]$ and carrier solvents were allowed to evaporate while control diet was prepared in the same way but chemical application was omitted. Larval growth was assessed as a percentage of the control after seven days of feeding and data were analyzed by analysis of variance (ANOVA) using SAS 8.01, 2000 and the means were compared by Tukey's multiple range test. 
To determine $\mathrm{EC}_{50}$ and $\mathrm{LC}_{50}$ values, 4th and 5th instar larvae were separately subjected to six different concentrations of DB, Ts $(0.6,0.5,0.4,0.3,0.2$, $\left.0.1 \mathrm{mg} \mathrm{ml}^{-1}\right)$ and $\mathrm{Bt}\left(2,4,6,8,10,12 \mu \mathrm{g} \mathrm{ml}^{-1}\right.$ or $0.002,0.004,0.006,0.008,0.010,0.012 \mathrm{mg} \mathrm{ml}^{-1}$ ). Mean effective concentrations $\left(\mathrm{EC}_{50}\right)$ were determined by regression analysis while lethal concentrations causing $50 \%$ mortality $\left(\mathrm{LC}_{50}\right)$ were determined using probit-log analysis.

$\mathrm{EC}_{50}$ values of these bio chemicals were further used in nutritional and enzyme analysis either individually or in combination with $\mathrm{Bt}$ and each other.

Mortality bioassay. Mortality bioassay was carried out using three concentrations of each $\mathrm{DB}$ [DB1 $\left(0.6 \mathrm{mg} \mathrm{ml}^{-1}\right)$, DB2 $\left(0.5 \mathrm{mg} \mathrm{ml}^{-1}\right)$, DB3 $(0.4$ $\left.\mathrm{mg} \mathrm{ml}^{-1}\right)$ ], Ts [Ts $1\left(0.6 \mathrm{mg} \mathrm{ml}^{-1}\right)$, Ts2 $\left(0.5 \mathrm{mg} \mathrm{ml}^{-1}\right)$, Ts3 $\left.\left(0.4 \mathrm{mg} \mathrm{ml}^{-1}\right)\right]$ and Bt [Bt1 $\left(12 \mu \mathrm{g} \mathrm{ml}^{-1}\right)$, Bt2 $\left.\left(10 \mu \mathrm{g} \mathrm{ml}^{-1}\right), \quad \mathrm{Bt} 3 \quad\left(8 \mu \mathrm{g} \mathrm{ml}^{-1}\right)\right]$ individually. In order to study the combined effects, combinations were made as DB1+Ts1, DB2+Ts2, DB3+Ts3, $\mathrm{DB} 1+\mathrm{Bt} 1, \mathrm{DB} 2+\mathrm{Bt} 2, \mathrm{DB} 3+\mathrm{Bt} 3, \mathrm{Ts} 1+\mathrm{Bt} 1, \mathrm{Ts} 2+$ $\mathrm{Bt} 2, \mathrm{Ts} 3+\mathrm{Bt} 3, \mathrm{DB} 1+\mathrm{Ts} 1+\mathrm{Bt} 1, \mathrm{DB} 2+\mathrm{Ts} 2+\mathrm{Bt} 2$, $\mathrm{DB} 3+\mathrm{Ts} 3+\mathrm{Bt} 3$. Newly molted 4th instar larvae were starved for $4 \mathrm{~h}$ before being exposed to treated diet. Larvae were left to feed on the treated diet until their death or pupation (normal or abnormal). Larval mortality was assessed on a daily basis and mortality percentage was calculated for each concentration at different time intervals to determine the time taken by larvae up to mortality against different chemicals and their combinations. Thirty larvae were used for each concentration with five replications. The experiment was repeated three times. Data were subjected to ANOVA using SAS 8.01, 2000 and the means were compared by Tukey's multiple range test.

Nutrition analysis. In order to clarify behavioral changes from the changes caused by the toxicity of chemicals, nutritional analysis was performed. The experiment was carried out using newly molted fourth instar larvae. Thirty larvae per concentration with five replications were provided with DB, Ts and $\mathrm{Bt}$ at concentrations $0.17,0.35$ and $0.0031 \mathrm{mg}$ $\mathrm{ml}^{-1}$ individually (based on $\mathrm{EC}_{50}$ values determined against this larval stage) and in combination $(\mathrm{DB}+\mathrm{Ts}, \mathrm{DB}+\mathrm{Bt}, \mathrm{Ts}+\mathrm{Bt}$ and $\mathrm{DB}+\mathrm{Ts}+\mathrm{Bt})$. Relative growth per unit weight (RGR) of the insect, relative consumption rate (RCR) and efficiency of conversion of ingested food (ECI) were calculated based on dry weight after 3 days of feeding (Koul et al., 1997). Data was subjected to ANOVA and the means were compared by Tukey's multiple range test (SAS, 2000).

Enzyme analysis. Newly molted fourth instar larvae were fed on artificial diet treated with $\mathrm{DB}$, $\mathrm{Ts}, \mathrm{Bt}, \mathrm{DB}+\mathrm{Ts}, \mathrm{DB}+\mathrm{Bt}, \mathrm{Ts}+\mathrm{Bt}, \mathrm{DB}+\mathrm{Ts}+\mathrm{Bt}$ $\left(0.17,0.35\right.$ and $0.0031 \mathrm{mg} \mathrm{ml}^{-1}$ based on $\mathrm{EC}_{50}$ values either individually or in combination against fourth instar larvae) and used for enzyme analysis. Larvae were alternatively provided with treated and untreated diet every $24 \mathrm{~h}$ to avoid high mortality rates and to observe the long-term effects on the antioxidant enzyme system in the fat bodies of larvae. Samples from fat bodies were collected randomly at 24-h intervals to observe depletion relevant to the control and were calculated as a percentage of the control. For enzyme analysis, 10 insects were randomly selected with an interval of $48 \mathrm{~h}$ up to 8 days. Insects were dissected to obtain fat bodies, which were homogenized in $0.05 \mathrm{~mol} \mathrm{~L}^{-1}$ phosphate buffer with $\mathrm{pH} 7.0$ at 0 to $4^{\circ} \mathrm{C}$. A Thomas glass homogenizer with a Teflon pestle was used to homogenize the samples. The homogenates obtained $(10 \% \mathrm{w} / \mathrm{v})$ were centrifuged at $6,000 \times g$ for $10 \mathrm{~min}$ at $4^{\circ} \mathrm{C}$ and the supernatant was used to measure enzyme activities.

Total SOD activity was measured using the method of Beauchamp and Fridovich (1971). This method is based on superoxide anion generation by reduced flavins under the influence of light, at room temperature. SOD catalyzes the dismutation of radicals and inhibits the formation of formazans.

Total CAT activity was measured by homogenizing fat bodies in $66 \mathrm{~mm}$ phosphate buffer ( $\mathrm{pH}$ 7.0). The reaction mixture was composed of $66 \mathrm{~mm}$ phosphate buffer ( $\mathrm{pH} 7.0$ ), sample extract and 3\% hydrogen peroxide. CAT activity was measured as the amount of $\mathrm{H}_{2} \mathrm{O}_{2}$ reduced per minute per milligram of protein (Aebi, 1984).

Protein concentrations in the supernatants were determined by the procedure of Bradford (1976), using bovine serum albumin (Sigma-Aldrich).

The enzyme assays were repeated 5 times. Data are presented as a percent increase or decrease over control at a specific time. Results were analyzed by Student's $t$ test using SAS 8.01, 2000 software and $p \leq 0.05$ was significant. 


\section{RESULTS}

\section{Efficacy of bio-chemicals}

Effect of $D B$ and Ts on growth, $E C_{50}$ and $L C_{50}$

$\mathrm{DB}$, Ts and Bt retarded the growth of early larval instars when incorporated into the artificial diet. A significant decrease in growth was observed with the increase in concentration relative to the control. The highest growth reduction was observed at DB1 (91.30\%), which was significantly different from the growth reduction at T1 $(84.17 \%)$ and Bt1 $(77.13 \%)(\mathrm{df}=17, F=155, p<0.05)$ as shown in Fig. 1.

$\mathrm{EC}_{50}$ values of $\mathrm{DB}$, Ts and Bt were $0.17 \mathrm{mg} \mathrm{ml}^{-1}$ (95\% confidence interval $0.10-0.25$ ) and 0.35 $\mathrm{mg} \mathrm{ml}^{-1}(0.25-0.54)$ and $0.0031 \mathrm{mg} \mathrm{m}^{-1}(0.0023-$ $0.0049)$, respectively, against 4 th instar larvae while the values remained $0.22 \mathrm{mg} \mathrm{ml}^{-1}(0.11-$ $0.29), \quad 0.41 \mathrm{mg} \mathrm{ml}^{-1}(0.30-0.58)$ and $0.0039 \mathrm{mg}$ $\mathrm{ml}^{-1}(0.0031-0.0061)$ against 5 th instar larvae (Table 1). Lethal concentrations causing 50\% mor- tality $\left(\mathrm{LC}_{50}\right)$ were $0.30 \mathrm{mg} \mathrm{m}^{-1}(0.25-0.38), 0.52$ $\mathrm{mg} \mathrm{ml}^{-1}(0.41-0.75)$ and $0.0068 \mathrm{mg} \mathrm{ml}^{-1}(0.0053-$ 0.0079 ) of $\mathrm{DB}$, Ts and Bt against 4th instar larvae whereas the values fell to $0.43 \mathrm{mg} \mathrm{ml}^{-1}(0.34$ $0.53), \quad 0.63 \mathrm{mg} \mathrm{ml}^{-1}(0.49-0.95)$ and $0.0071 \mathrm{mg}$ $\mathrm{ml}^{-1}(0.0060-0.0085)$ against 5 th instar larvae of S. exigua (Table 2 ).

\section{Effect of $D B$, Ts and Bt on mortality}

Dose-dependent mortality was observed with individual treatments of $\mathrm{DB}$, Ts and $\mathrm{Bt}$. The highest mortality in individual treatments reached 90, 76.67 and $65.81 \%$ against $\mathrm{DB}$, Ts and $\mathrm{Bt}$ on the 8 th day. In combinations, the mortality percentage significantly increased from individual treatments with shorter exposure time. The highest mortality percentage $(94.2 \%)$ was noted on the 6th day with $\mathrm{DB} 1+\mathrm{Ts} 1+\mathrm{Bt} 1$. The combination of $\mathrm{DB}$ and Ts resulted in decreased efficiency of DB as the highest mortality noted was $78.20 \%$, as compared to individual DB treatments with $90 \%$ mortality on the 8th day. Ts produced better results with Bt with

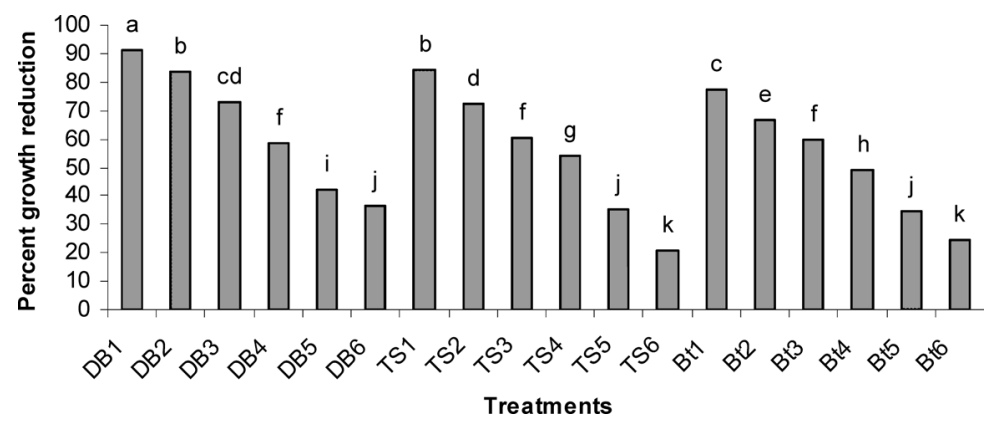

Fig. 1. Growth inhibition caused by different treatments of DB, Ts and Bt relative to control in early insect instars. Each point expresses the mean \pm standard error of five replicates. Means followed by the same letter above bars have no significance difference $(p \leq 0.05)$ according to Tukey's test. DB1, destruxin B $(90 \mu \mathrm{g} / \mathrm{ml}) ; \mathrm{DB} 2$, destruxin B $(75 \mu \mathrm{g} / \mathrm{ml})$; DB3, destruxin B $(60 \mu \mathrm{g} / \mathrm{ml})$; DB4, destruxin B (45 $\mu \mathrm{g} / \mathrm{ml})$; DB5, destruxin B $(30 \mu \mathrm{g} / \mathrm{ml})$; DB6, destruxin B (15 $\mu \mathrm{g} / \mathrm{ml})$; Ts1, tea saponin $(90 \mu \mathrm{g} / \mathrm{ml})$; Ts2, tea saponin $(75 \mu \mathrm{g} / \mathrm{ml})$; Ts3, tea saponin $(60 \mu \mathrm{g} / \mathrm{ml})$; Ts4, tea saponin $(45 \mu \mathrm{g} / \mathrm{ml})$; Ts5, tea saponin $(30 \mu \mathrm{g} / \mathrm{ml})$; Ts6, tea saponin $(15 \mu \mathrm{g} / \mathrm{ml})$; Bt1, B. thuringiensis $(1.90 \mu \mathrm{g} / \mathrm{ml})$; Bt2, B. thuringiensis $(1.60 \mu \mathrm{g} / \mathrm{ml}) ; \mathrm{Bt} 3$, B. thuringiensis $(1.30 \mu \mathrm{g} / \mathrm{ml}) ; \mathrm{Bt} 4$, B. thuringiensis $(1.0 \mu \mathrm{g} / \mathrm{ml})$; Bt5, B. thuringiensis $(0.70 \mu \mathrm{g} / \mathrm{ml})$; Bt6, B. thuringiensis $(0.40 \mu \mathrm{g} / \mathrm{ml})$.

Table 1. $\mathrm{EC}_{50}$ and $\mathrm{EC}_{95}$ values $\left(\mathrm{mg} \mathrm{ml}^{-1}\right)$ of $\mathrm{DB}$, Ts and $\mathrm{Bt}$ to 4 th and 5 th instar larvae of S. exigua

\begin{tabular}{lcccccc}
\hline \multicolumn{1}{c}{ Compounds } & $\mathrm{EC}_{50}$ & $\mathrm{CI} 95 \%$ & $\mathrm{EC}_{95}$ & $\mathrm{CI} 95 \%$ & Slope & $\chi^{2}$ \\
\hline DB (4th instar) & $0.17 \pm 0.05$ & $0.10-0.25$ & $1.10 \pm 0.12$ & $0.83-3.10$ & $1.54 \pm 0.20$ & 5.10 \\
DB (5th instar) & $0.22 \pm 0.04$ & $0.11-0.29$ & $2.01 \pm 0.10$ & $0.91-4.12$ & $1.89 \pm 0.23$ & 5.99 \\
Ts (4th instar) & $0.35 \pm 0.06$ & $0.25-0.54$ & $1.90 \pm 0.14$ & $1.09-5.77$ & $1.98 \pm 0.22$ & 6.35 \\
Ts (5th instar) & $0.41 \pm 0.07$ & $0.30-0.58$ & $2.33 \pm 0.11$ & $1.21-5.99$ & $2.15 \pm 0.21$ & 4.03 \\
Bt (4th instar) & $0.0031 \pm 0.0004$ & $0.0023-0.0049$ & $0.00873 \pm 0.0007$ & $0.0082-0.0091$ & $2.43 \pm 0.45$ & 1.73 \\
Bt (5th instar) & $0.0039 \pm 0.0006$ & $0.0031-0.0061$ & $0.0098 \pm 0.0004$ & $0.0089-0.011$ & $2.37 \pm 0.41$ & 3.04
\end{tabular}

DB, destruxin B; Ts, tea saponin; Bt, B. thuringiensis kurstaki. 
Table 2. $\mathrm{LC}_{50}$ and $\mathrm{LC}_{95}$ values $\left(\mathrm{mg} \mathrm{ml}^{-1}\right)$ of $\mathrm{DB}$, Ts and $\mathrm{Bt}$ to 4 th and 5 th instar larvae of $S$. exigua

\begin{tabular}{lcccrrr}
\hline \multicolumn{1}{c}{ Compounds } & LC $_{50}$ & CI 95\% & LC $_{95}$ & CI 95\% & Slope & $\chi^{2}$ \\
\hline DB (4th instar) & $0.30 \pm 0.02$ & $0.25-0.38$ & $1.46 \pm 0.14$ & $0.84-2.01$ & $2.41 \pm 0.27$ & 5.71 \\
DB (5th instar) & $0.43 \pm 0.11$ & $0.34-0.53$ & $1.97 \pm 0.16$ & $1.12-2.35$ & $2.49 \pm 0.26$ & 4.22 \\
Ts (4th instar) & $0.52 \pm 0.05$ & $0.41-0.75$ & $2.24 \pm 0.10$ & $1.39-4.77$ & $2.71 \pm 0.83$ & 3.66 \\
Ts (5th instar) & $0.63 \pm 0.14$ & $0.49-0.95$ & $2.78 \pm 0.13$ & $1.98-6.87$ & $2.98 \pm 0.87$ & 7.46 \\
Bt (4th instar) & $0.0068 \pm 0.0005$ & $0.0053-0.0079$ & $0.013 \pm 0.0007$ & $0.012-0.014$ & $2.57 \pm 0.35$ \\
Bt (5th instar) & $0.0071 \pm 0.0005$ & $0.0060-0.0085$ & $0.020 \pm 0.0009$ & $0.0177-0.024$ & $1.62 \pm 0.45$ & 5.87 \\
\hline
\end{tabular}

DB, destruxin B; Ts, tea saponin; Bt, B. thuringiensis kurstaki.

$80.67 \%$ mortality, particularly when the three were mixed at different concentrations. The combination of DB and Bt resulted in high increased efficiency of both with $91.99 \%$ mortality, especially in comparison to individual Bt treatment, which resulted in $65.81 \%$ mortality (Table 3 ).

\section{Nutritional efficiency}

Nutritional analysis after feeding larvae on treated diet showed that these bio-chemicals proved toxic to some extent when ingested by larvae. $\mathrm{EC}_{50}$ $\left(0.17,0.35\right.$ and $0.0031 \mathrm{mg} \mathrm{ml}^{-1}$ of $\mathrm{DB}$, Ts and $\mathrm{Bt}$, respectively) values were used either individually or in combination for this experiment. There was a decrease in RCR, RGR and ECI as compared to the control. In individual treatments, RCR and RGR values of larvae fed on $\mathrm{DB}$, Ts and $\mathrm{Bt}$ were 2.84, $3.92,3.07 \mathrm{mg} / \mathrm{mg} /$ day and $1.45,2.20$ and $1.73 \mathrm{mg} /$ $\mathrm{mg} /$ day, respectively. The lowest RCR, RGR values were found with $\mathrm{DB}+\mathrm{Bt}, 2.69 \mathrm{mg} / \mathrm{mg} /$ day and $1.33 \mathrm{mg} / \mathrm{mg} /$ day and $35.33 \%$ of the control, respectively. Ts also showed better results, with Bt having significant lower values of RCR and RGR than individual treatment. The combination of $\mathrm{DB}+\mathrm{Ts}$ improved Ts efficiency and the results of RCR; RGR was significantly different from individual Ts treatment (Table 4).

\section{Enzyme analysis}

Fat body weight of insects changed over time up to the final day (8th day) in comparison to the control. The maximum reduction in fat body weight $(48 \%)$ was obtained on the 8th day after being treated with $\mathrm{DB}$, whereas the minimum reduction was found after one day of treatment with $\mathrm{Ts}+\mathrm{Bt}$ $(11.67 \%)$ relative to the control (Fig. 2). A general trend of increased reduction on the final day, in relation to the control, was found, except with Ts and $\mathrm{DB}+\mathrm{Ts}+\mathrm{Bt}$ treatments where, after a certain in- crease, it decreased on the final day (Fig. 2).

When fourth instar larvae were exposed to artificial diet treated with DB, Ts and Bt individually (at $\mathrm{EC}_{50}$ values) or in combination there was a certain change in SOD and CAT activity of treated larvae in comparison to the control (Tables 5 and 6 ) at different exposure times. With SOD, the highest variation in activity compared to the control was found on the 6th day after DB treatment $(+29.21 \%)$ and the lowest activity was noted on the 8 th day $(-5.30 \%)$ after treatment with $\mathrm{DB}+\mathrm{Bt}$ (Table 5). The maximum CAT activity was found on the 6th day $(+24.64 \%)$ after treatment with Bt whereas the lowest value was noted on the 8th day $(-9.51 \%)$ after DB treatment (Table 6). All chemicals changed SOD and CAT activity to some extent but with a common trend of decreased values on the final days, but the decrease in values with $\mathrm{Bt}$ was not as sharp as with other treatments (Tables 5 and 6).

\section{DISCUSSION}

Synthetic insecticides have proven toxic to beneficial insects, such as natural parasitoids and predators (Abudulai et al., 2001). The best alternative may be biochemicals obtained from natural origins, including plants, fungi or bacteria. In this study, three biochemicals were tested, either individually or in combination, and exhibited some toxicity against $S$. exigua, although some combinations exhibited higher efficiency than others. These chemicals significantly affected larval growth, nutrition efficiency and had important poisonous effects on S. exigua larvae, and their efficiency was increased when used in combination. This toxicity appeared to be related with decreased larval weight and inhibition of development. Such disruptions were often 


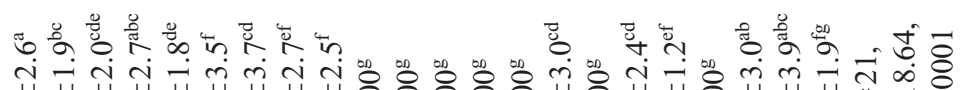

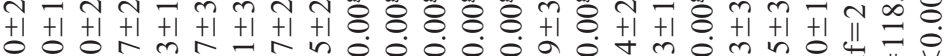

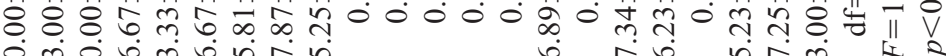
वंल

:

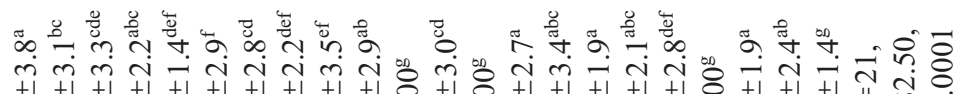

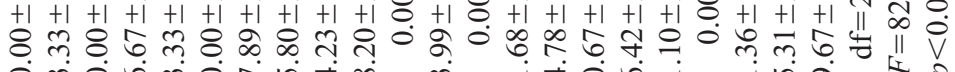
$\therefore$ हिं

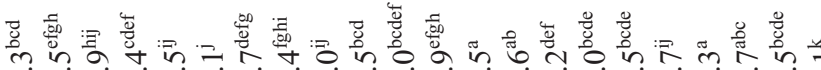

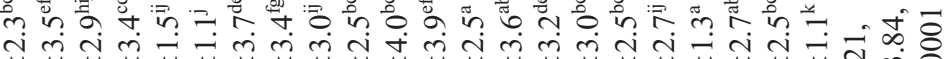

6

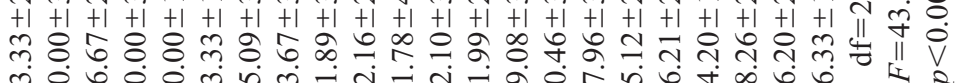

लं

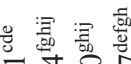

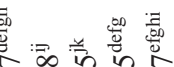

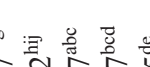

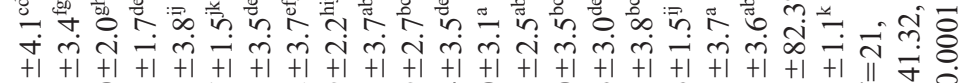

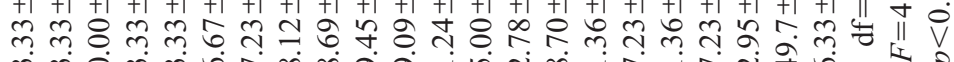

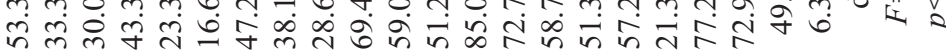

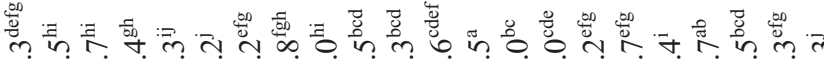

4imiticimo

$+1+1+1+1+1+1+1+1+1+1+1+1+1+1+1+1+1+1+1+1+1+1 \pi n$

m \& \& \& 8 8

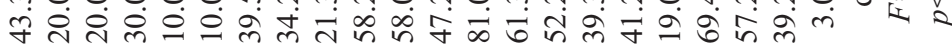

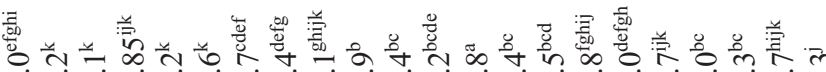

तสm-

$+1+1+1+1+1+1+1+1+1+1+1+1+1+1+1+1+1+1+1+1+1+1$ N

ธิธย

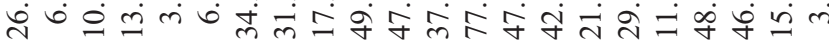

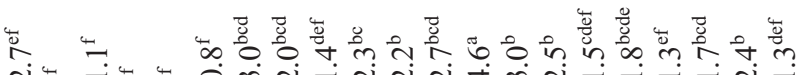

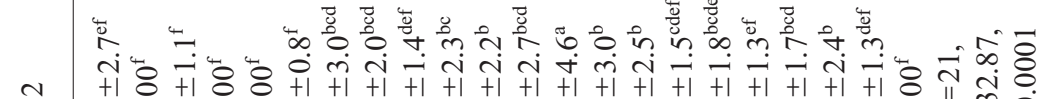

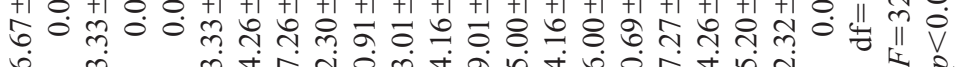

0 c

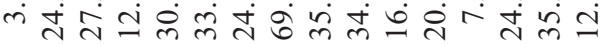

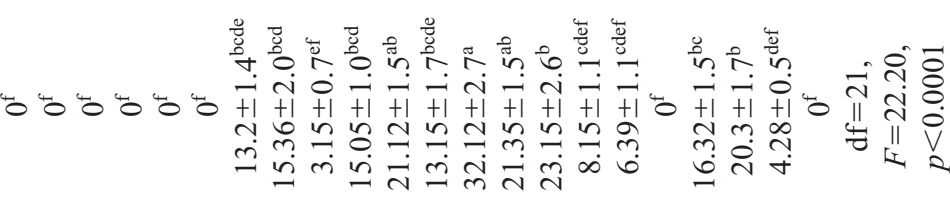

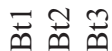

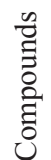

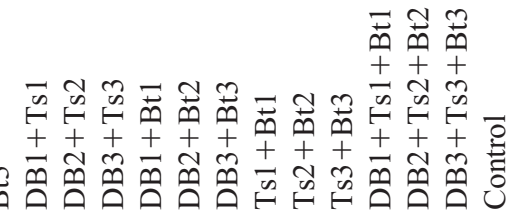

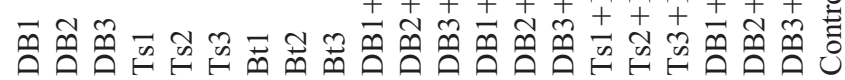

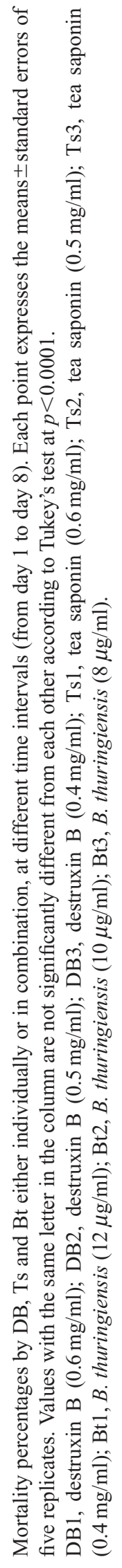


described in insects reared on extracts from natural resources or on pure allelochemicals with insecticidal activity (Rharrabe et al., 2007).

Table 4. Feeding, growth and efficiency of conversion of ingested food by 4 th instar larvae of $S$. exigua

\begin{tabular}{lccc}
\hline Compounds & $\begin{array}{c}\text { RCR } \\
(\mathrm{mg} / \mathrm{mg} / \mathrm{day})\end{array}$ & $\begin{array}{c}\text { RGR } \\
(\mathrm{mg} / \mathrm{mg} / \mathrm{day})\end{array}$ & ECI (\%) \\
\hline $\mathrm{DB}$ & $2.84 \pm 0.13^{\mathrm{cde}}$ & $1.45 \pm 0.14^{\mathrm{c}}$ & $37.33 \pm 2.90^{\mathrm{ab}}$ \\
Ts & $3.92 \pm 0.12^{\mathrm{b}}$ & $2.20 \pm 0.10^{\mathrm{b}}$ & $46.10 \pm 1.53^{\mathrm{ab}}$ \\
$\mathrm{Bt}$ & $3.07 \pm 0.10^{\mathrm{bc}}$ & $1.73 \pm 0.17^{\mathrm{bc}}$ & $43.19 \pm 3.29^{\mathrm{ab}}$ \\
$\mathrm{DB}+\mathrm{Ts}$ & $3.39 \pm 0.13^{\mathrm{bc}}$ & $1.55 \pm 0.15^{\mathrm{bc}}$ & $45.33 \pm 5.61^{\mathrm{ab}}$ \\
$\mathrm{DB}+\mathrm{Bt}$ & $2.69 \pm 0.16^{\mathrm{de}}$ & $1.33 \pm 0.09^{\mathrm{c}}$ & $35.77 \pm 2.85^{\mathrm{b}}$ \\
Ts $+\mathrm{Bt}$ & $2.99 \pm 0.16^{\mathrm{cd}}$ & $1.77 \pm 0.11^{\mathrm{bc}}$ & $44.21 \pm 3.05^{\mathrm{ab}}$ \\
DB+Ts+Bt & $3.37 \pm 0.08^{\mathrm{bc}}$ & $2.14 \pm 0.13^{\mathrm{bc}}$ & $44.98 \pm 3.75^{\mathrm{ab}}$ \\
Control & $6.05 \pm 0.15^{\mathrm{a}}$ & $3.11 \pm 0.19^{\mathrm{a}}$ & $52.23 \pm 3.26^{\mathrm{a}}$
\end{tabular}

Mean values within a column with different letters are significantly different at $p \leq 0.05$ based on Tukey's test.

$\mathrm{RCR}$, relative consumption rate; RGR, relative growth rate;

ECI, efficiency of conversion of ingested food.

$\mathrm{DB}$, destruxin B; Ts, tea saponin; Bt, B. thuringiensis kurstaki.
The mortality caused by individual and different combined treatments of biochemicals was found to be concentration and time (exposure period) dependent. The combination of DB1+Ts1+Bt1 was found to be the most lethal with highest mortality (94.2\%). The combination of $\mathrm{Ts}+\mathrm{Bt}$ at different concentrations exhibited the significantly increased efficiency of both as compared to individual performance and the highest mortality was caused by Ts1+Bt1 (80.67\%), which was much higher than the highest mortality caused by individual Ts $(76.66 \%)$ and Bt1 (65.81\%). Lower mortality in individual Bt treatment could be because of stable SOD and CAT values in the final days (Tables 5 and 6). These results show the working compatibility of DB and Ts with Bt against $S$. exigua. Similar results were found by Gould et al. (1991) as they observed increased mortality with the addition of $\mathrm{Bt}$ to plant extracts. The combination of $\mathrm{DB}+\mathrm{Ts}$ resulted in decreased mortality as compared to the individual performance of DB.

Some scientists believe that insecticidal activi-

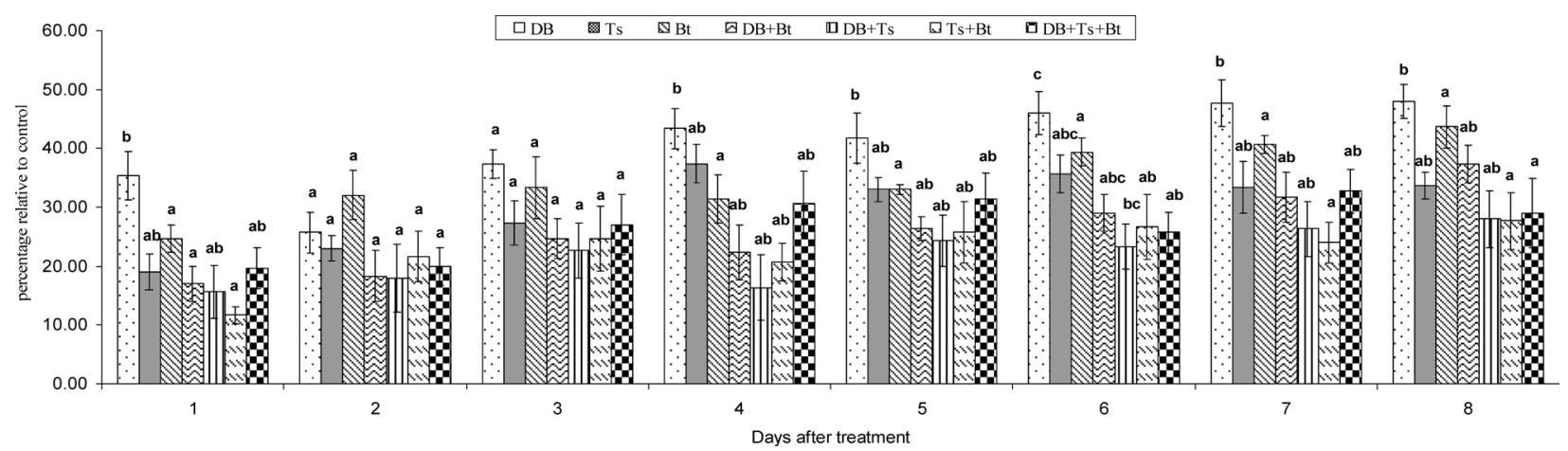

Fig. 2. Effect of biochemicals (DB, Ts, Bt) individually or in combination with each other (based on their respective $\mathrm{EC}_{50} \mathrm{val}_{-}$ ues), on the fat body weight of $S$. exigua larvae. Each point expresses the mean \pm standard error of five replicates. Means followed by the same letter above bars have no significance difference $(p \leq 0.05)$ according to Tukey's test. DB, destruxin B; Ts, tea saponin; $\mathrm{Bt}$, B. thuringiensis kurstaki.

Table 5. Effect of biochemicals on total superoxide dismutase (SOD) activity in fat bodies

\begin{tabular}{|c|c|c|c|c|c|c|c|}
\hline \multirow{2}{*}{$\begin{array}{l}\text { Time of } \\
\text { exposure } \\
\text { (days) }\end{array}$} & \multicolumn{7}{|c|}{ SOD (\% over control) } \\
\hline & DB & Ts & $\mathrm{Bt}$ & $\mathrm{DB}+\mathrm{Ts}$ & $\mathrm{DB}+\mathrm{Bt}$ & $\mathrm{Ts}+\mathrm{Bt}$ & $\mathrm{DB}+\mathrm{Ts}+\mathrm{Bt}$ \\
\hline 2 & $13.54+*$ & $9.02+*$ & $11.43+*$ & $5.12+\mathrm{ns}$ & $13.15+\mathrm{ns}$ & $9.54+*$ & $5.04+\mathrm{ns}$ \\
\hline 4 & $27.40+*$ & $15.94+\mathrm{ns}$ & $16.69+*$ & $13.69+\mathrm{ns}$ & $23.51+*$ & $18.01+\mathrm{ns}$ & $14.40+\mathrm{ns}$ \\
\hline 6 & $29.21+*$ & $21.87+\mathrm{ns}$ & $21.27+\mathrm{ns}$ & $25.43+\mathrm{ns}$ & $18.25+*$ & $16.48+\mathrm{ns}$ & $19.97+*$ \\
\hline 8 & $3.24-\mathrm{ns}$ & $2.02+*$ & $18.95+*$ & $7.48+*$ & $5.30-\mathrm{ns}$ & $8.47+*$ & $6.80+\mathrm{ns}$ \\
\hline
\end{tabular}

* Significantly different from the control $(\alpha=0.05)$. ns, not significant.

,$+ \%$ increase over control;,$- \%$ decrease over control.

$\mathrm{DB}$, destruxin B; Ts, tea saponin; Bt, B. thuringiensis kurstaki. 
Table 6. Effect of biochemicals on total catalase (CAT) activity in fat bodies

\begin{tabular}{|c|c|c|c|c|c|c|c|}
\hline \multirow{2}{*}{$\begin{array}{c}\text { Time of } \\
\text { exposure } \\
\text { (days) }\end{array}$} & \multicolumn{7}{|c|}{ CAT ( $\%$ over control) } \\
\hline & DB & Ts & $\mathrm{Bt}$ & $\mathrm{DB}+\mathrm{Ts}$ & $\mathrm{DB}+\mathrm{Bt}$ & $\mathrm{Ts}+\mathrm{Bt}$ & $\mathrm{DB}+\mathrm{Ts}+\mathrm{Bt}$ \\
\hline 2 & $7.50+\mathrm{ns}$ & $12.30+\mathrm{ns}$ & $9.63+*$ & $4.12+\mathrm{ns}$ & $10.47+\mathrm{ns}$ & $8.73+\mathrm{ns}$ & $13.67+\mathrm{ns}$ \\
\hline 4 & $19.21+^{*}$ & $16.69+*$ & $18.09+\mathrm{ns}$ & $8.44+\mathrm{ns}$ & $14.58+*$ & $14.89+*$ & $14.97+*$ \\
\hline 6 & $15.89+*$ & $23.57+*$ & $24.64+*$ & $11.98+*$ & $16.20+*$ & $15.23+^{*}$ & $11.91+\mathrm{ns}$ \\
\hline 8 & $9.51-*$ & $1.68-\mathrm{ns}$ & $13.42+*$ & $1.79+\mathrm{ns}$ & $7.07+\mathrm{ns}$ & $1.51+\mathrm{ns}$ & $4.48+\mathrm{ns}$ \\
\hline
\end{tabular}

* Significantly different from the control $(\alpha=0.05)$. ns, not significant.

,$+ \%$ increase over control;,$- \%$ decrease over control.

$\mathrm{DB}$, destruxin B; Ts, tea saponin; Bt, B. thuringiensis kurstaki.

ties of destruxins are due to the combination of starvation and toxicity effects (Amiri et al., 1999). This phenomenon was confirmed in our experiment, as the RCR value against DB was considerably lower than $\mathrm{Ts}$ and $\mathrm{Bt}$ in individual treatments. The lowest RCR value noted with $\mathrm{DB}+\mathrm{Bt}$ exhibited the higher interactive ability of the two, as there was a considerable decrease in comparison to individual treatments. The same results were found with $\mathrm{DB}+\mathrm{Bt}$ with the lowest RGR values. The combination of Ts and Bt resulted in significantly lower RCR and RGR values than individual treatments of Ts without effecting the ECI value. Significantly lower ECI values against $\mathrm{DB}+\mathrm{Bt}$ confirmed the multidimensional impact on the insect as reduced ECI can result from the decreased efficiency of $S$. exigua to change the consumed food into growth, perhaps by diverting energy from biomass production into detoxification. Strong antifeedant activity of DB has also been documented by many researchers, such as $\mathrm{Hu}$ et al. (2007), who identified antifeedant activity of DB against Spodoptera litura. On the other side, fourth instar $S$. exigua larvae were relatively insusceptible to individual Ts treatment as it caused less reduction in growth and ECI, as noticed by Adel et al. (2000), who have reported that treated $S$. littoralis gained almost the same weight as the control; however, in our experiment, increased toxicity of Ts was observed when mixed with $\mathrm{Bt}$ with lower RGR, RCR and ECI values as compared to individual treatment of Ts.

Fat bodies of insects had been the focus of study by many scientists and were reported to be a source of high metabolic rates in herbivorous insects (Ahmad et al., 1991). In our experiment, all biochemicals, individually or in combination, not only caused the depletion of fat body weight as compared to the control but increased activities of SOD and CAT enzymes in fat bodies were also noted. Similarly Adamski et al. (2003) and Yu (2004) found fluctuations in the activities of different enzymes in fat bodies after the exposure of insects to different chemicals. Fat bodies are supposed to be sensitive to toxicity and play a vital role in the detoxification of insecticides with increased enzyme activities, as Kafel et al. (2003) reported that the increase in enzyme activities in fat bodies is dependent on exposure time.

Antioxidant enzymes SOD and CAT play a vital role in detoxifying destructive oxidant species by catalyzing the detoxification of $\mathrm{O}_{2}^{--}$to $\mathrm{O}_{2}$ and $\mathrm{H}_{2} \mathrm{O}_{2}$, SOD blocks $\mathrm{O}_{2}{ }^{--}$-driven cell damage (McCord and Fridovich, 1969). CAT can break down $\mathrm{H}_{2} \mathrm{O}_{2}$ to $\mathrm{H}_{2} \mathrm{O}$ and $\mathrm{O}_{2}$. Biochemicals can effect many enzymatic activities in different tissues where cells are producing enzymes (Timmins and Reynolds, 1992). Enhanced activity of antioxidant enzymes play an important role in the insect immune system and can be a cause of resistance. In this study, we found significantly higher values of these enzymes at different intervals when compared to the control, which confirms the presence of an antioxidant defense system in the insect body. The maximum SOD value was observed with individual DB treatment after 6 days of treatment. The highest CAT value was observed on the 6th day of individual $\mathrm{Bt}$ treatment. The combination of all biochemicals $(\mathrm{DB}+\mathrm{Ts}+\mathrm{Bt})$ resulted in suppressed SOD values but did not differ significantly from the control except on day 6 and after 4 days of treatment with CAT. The values of these enzymes may fluctuate as documented by researchers (Casano et al., 1997; Cakmak, 2000) that high lev- 
els of $\mathrm{H}_{2} \mathrm{O}_{2}$ inhibit SOD through the formation of excess hydroxyl radicals, whereas the CAT enzyme is sensitive to $\mathrm{O}_{2}{ }^{-}$and can be inactivated by its increased levels. The activity of these enzymes fell with the increased exposure time, except with Bt, indicating that the detoxification mechanism was unable to match the stress produced by DB and Ts (Sowjanya and Padmaja, 2008). The lower enzyme activities on the final days could have been the cause of the lower survival (Adamczyk et al., 2003).

To summarize, this study not only establishes the bioinsecticidal effects of DB and Ts on the growth, mortality and nutritional aspects of $S$. exigua but also provides a comparison with Bt and their compatibility in combination, especially with Bt. This information can be helpful to increase the efficacy of not only these biochemicals but this phenomenon can also be used with other biochemicals from natural sources against different insect species. This study also provides information about the activity of antioxidant enzymes against these biochemicals, as antioxidant enzymes are supposed to be involved in the resistance mechanism of insects, so these investigations should be helpful to establish the relationship between biochemicals from natural resources and the defense system of insects, which can further enhance their activities and the better control of insects.

\section{ACKNOWLEDGEMENTS}

The authors gratefully acknowledge the role of the National Science Foundation of the People's Republic of China in funding this work under grant no. 30671387 . The authors are also grateful for support from the Foundation for the Author of National Excellent Doctorial Dissertation of P. R. China (FANEDD, No. 2004061).

\section{REFERENCES}

Abudulai, M., B. M. Shepard and P. L. Mitchell (2001) Parasitism and predation on eggs of Leptoglossus phyllopus (L.) (Hemiptera: Coreidae) in cowpea: impact of endosulfan sprays. J. Agric. Urban Entomol. 18: 105-115.

Adamczyk, J. J., M. R. Williams and J. T. Reed (2003) Spatial and temporal occurrence of beet armyworm (Lepidoptera: Noctuidae) moths in Mississippi. Fla. Entomol. 86: 229-232.

Adamski, Z. and K. Ziemnicki (2004) Side-effects of mancozeb on Spodoptera exigua (Hübn.) larvae. J. Appl. Ent. 128: 212-217.

Adamski, Z., K. Ziemnicki, K. Fila, R. V. Zickic and A. Stajn (2003) Effects of long term exposure to fenitrothion on Spodoptera exigua and Tenebrio molitor larval develop- ment and antioxidant enzyme activity. Biol. Lett. 40: 43-52.

Adel, M. M., F. Sehnal and M. Jurzysta (2000) Effects of alfalfa saponins on the moth Spodoptera littoralis. $J$. Chem. Ecol. 26: 1065-1078.

Aebi, H. (1984) Catalase in vitro. Methods Enzymol. 105: 121-126.

Ahmad, S., D. L. Duval, L. C. Weinhold and R. S. Pardini (1991) Cabbage looper antioxidant enzymes: tissue specificity. Insect Biochem. 21: 563-572.

Amiri, B., L. Ibrohim and T. M. Butt (1999) Antifeedant properties of destruxins and their potential use with the entomogenous fungus Metarhizium anisopliae for improved control of crucifer pests. Biocontrol Sci. Techn. 4: 487-498.

Beauchamp, C. H. and I. Fridovich (1971) Superoxide dismutase: improved assays and assay applicable to acrylamide gels. Anal. Biochem. 44: 276-287.

Bradford, M. (1976) A rapid and sensitive method for the quantitation of microgram quantities of protein utilizing the principle of protein-dye binding. Anal. Biochem. 72: $248-254$.

Brousseua, C., G. Charpentier and S. Belloncik (1998) Effects of Bacillus thuringiensis and destruxins (Metarhizium anisopliae mycotoxins) combinations on spruce budworm (Lepidoptera: Tortricidae). J. Invertebr. Pathol. 72: 262-268.

Cakmak, I. (2000) Possible role of zinc in protecting plant cells from damage by reactive oxygen species. New Phytol. 146: 185-205.

Casano, L. M., L. D. Gomez, H. R. Lascano, C. A. Gonzalez and V. S. Trippi (1997) Inactivation and degradation of $\mathrm{Cu} / \mathrm{Zn}$ SOD by active oxygen species in wheat chloroplasts exposed to photooxidative stress. Plant Cell. Physiol. 38: 433-440.

David, W., S. Ellaby and G. Taylor (1975) Rearing Spodoptera exempta on semi-synthetic diets and on growing maize. Entomol. Exp. Appl. 19: 226-236.

Felton, G. W. and J. A. Gatehouse (1996) Antinutritive plant defense mechanisms. In Biology of the Insect Midgut (M. J. Lehane and P. F. Billingsley, eds.). Chapman and Hall, London, pp. 373-416.

Gill, S. S., E. A. Cowles and P. V. Pietrantonio (1992) The mode of action of Bacillus thuringiensis endotoxins. Annu. Rev. Entomol. 37: 236-615.

Gould, F., A. Anderson, D. Landis and J. Van Mellaert (1991) Feeding behaviour and growth of Heliothis virescens larvae on diets containing Bacillus thuringiensis formulations of endotoxins. Entomol. Exp. Appl. 96: 199-210.

Harris, E. D. (1992) Regulation of antioxidant enzymes. FASEB J. 6: 2675-2683.

Hu, Q., S. Ren, J. Wu, J. Chang and D. P. Musa (2006) Investigation of destruxin A and B from 80 Metarhizium strains in China and the optimization of cultural conditions for the strain MaQ10. Toxicon 48: 491-498.

Hu, Q., S. Ren, X. C. An and M. H. Qianm (2007) Insecticidal activity influence of destruxins on the pathogenicity of Paeciliomyces javanicus against Spodoptera litura. J. Appl. Entomol. 131: 262-268. 
Jacques, M. M., D. Ema and C. B. Jacqueline (2008) Nutrient utilization by caterpillars of the generalist beet armyworm, Spodoptera exigua. Physiol. Entomol. 33: 51-61.

Joanisse, D. R. and K. B. Storey (1996) Fatty acid content and enzymes of fatty acid metabolism in overwintering cold-hardy gall insects. Physiol. Zool. 69: 1079-1095.

Kafel, A., K. Bendaska, M. Augustyniak, I. Witas and S. Elzbieta (2003) Activity of glutathione $S$-transferase in Spodoptera exigua exposed to cadmium and zinc in two subsequent generations. Environ. Int. 28: 683-686.

Koul, O., M. J. Smirle and M. B. Isman (1990) Asarones from Acorus calamus L. oil: their effect on feeding behaviour and dietary utilization in Peridroma saucia. J. Chem. Ecol. 16: 1911-1920.

Koul, O., J. S. Shankar, N. Mehta, S. C. Taneja, A. K. Tripathi and K. L. Dhar (1997) Bioefficacy of crude extracts of Aglaia species (Meliaceae) and some active fractions against lepidopteran larvae. J. Appl. Entomol. 121: 245-248.

Liu, C. M., S. S. Huang and Y. M. Tzeng (2004) Purification and quantitative analysis of destruxins from Meterhizium anisopliae by HPLC. J. Liq. Chromatogr. R. T. 27: 1013-1025.

Luo, L. Z., Y. Z. Cao and X. F. Jiang (2000) Occurrence characteristics and analysis on trend of Spodoptera exigua (Hübner). Plant Prot. 26: 37-39.

McCord, J. M. and I. Fridovich (1969) Superoxide dismutase. J. Biol. Chem. 244: 6049-6055.

Moulton, J. K., D. A. Pepper and T. J. Dennehy (2000) Beet armyworm (Spodoptera exigua) resistance to spinosad. Pestic. Manag. Sci. 56: 842-848.

Pais, M., B. C. Das and P. Ferron (1981) Depsipeptides from Metarhizium anisopliae. Phytochemistry 20: 715-723.

Rharrabe, K., A. Bakrim, N. Ghailani and F. Sayah (2007) Bioinsecticidal effect of harmaline on Plodia interpunctella development (Lepidoptera: Pyralidae). Pestic Biochem. Physiol. 89: 137-145.

SAS Institute (2000) SAS User's Guide, version 8.01 statistics. SAS Institute, Cary, N.C.

Senthil Nathan, S., K. Kailavani and K. Murugan (2006) Behavioural responses and changes in biology of rice leaf- folder following treatment with a combination of bacterial toxins and botanical insecticides. Chemosphere 64: $1650-1658$.

Shimada, K., K. Natsuhara, Y. Oomori and T. Miyata (2005) Permethrin resistance mechanisms in the beet armyworm (Spodoptera exigua) (Hübner). J. Pestic. Sci. 30: 214219.

Sowjanya, S. K. and V. Padmaja (2008) Destruxin from Metarhizium anisopliae induces oxidative stress effecting larval mortality of the polyphagous pest Spodoptera litura. J. Appl. Entomol. 132: 68-78.

Suzuki, T., H. Nojiri, H. Isono and T. Ochi (2004) Oxidative damages in isolated rat hepatocytes treated with the organochlorine fungicides captan, dichlofluanid and chlorothalonil. Toxicology 204: 97-107.

Tabashnik, B. E. and Y. Carriere (2004) Bt transgenic crops do not have favorable effects on resistant insects. J. Insect Sci. 4: 1-4.

Timmins, W. A. and S. E. Reynolds (1992) Azadirachtin inhibits secretion of trypsin in midgut of Manduca sexta caterpillars: reduced growth due to impaired protein digestion. Entomol. Exp. Appl. 63: 47-54.

Ujvary, I. (2002) Transforming natural products into natural pesticides experience and expectations. Phytoparasitica 30: $1-4$.

Wang, K. Y., X. Y. Jiang, M. Q. Yi and B. K. Chen (2001) Studies on resistance change and management strategy of Spodoptera exigua (Hübner). Chin. J. Pestic. 40: 29-32.

Wu, S. C., Y. Z. Gu, Z. L. Sheng and H. Z. Zheng (1995) Monitoring of insecticides resistance and chemical control in beet army moth. Acta Phytophylacica Sin. 22: 95-96.

Yang, Y., Y. Wu, S. Chen, G. J. Devine, I. Denholm, P. Jewess and G. D. Moores (2004) The involvement of microsomal oxidases in pyrethroid resistance in Helicoverpa armigera from Asia. Insect Biochem. Mol. Biol. 34: $763-773$.

Yu, S. J. (2004) Induction of detoxification enzymes by triazine herbicides in the fall armyworm, Spodoptera frugiperda (J. E. Smith, ed.). Pestic. Biochem. Physiol. 80: $113-122$. 